Published in final edited form as:

J Control Release. 2014 April 10; 179: 33-41. doi:10.1016/j.jconrel.2014.01.006.

\title{
Topical Delivery of siRNA into Skin using SPACE-peptide Carriers
}

\author{
Ming Chen ${ }^{1, a}$, Michael Zakrewsky $^{1, a}$, Vivek Gupta ${ }^{1,2}$, Aaron C. Anselmo ${ }^{1}$, Deborah H. Slee ${ }^{3}$,

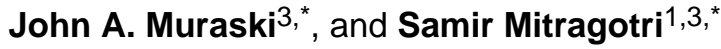 \\ ${ }^{1}$ Center for Bioengineering, Department of Chemical Engineering, University of California, Santa \\ Barbara, CA 93106 \\ ${ }^{3}$ Convoy Therapeutics, 405 W Cool Drive, Suite 107, Oro Valley, Arizona 85704
}

\section{Abstract}

\begin{abstract}
Short-interfering RNAs (siRNAs) offer a potential tool for the treatment of skin disorders. However, applications of siRNA for dermatological conditions are limited by their poor permeation across the stratum corneum of the skin and low penetration into skin's viable cells. In this study, we report the use of SPACE-peptide in combination with a DOTAP-based ethosomal carrier system to enhance skin delivery of siRNA. A DOTAP-based SPACE Ethosomal System significantly enhanced siRNA penetration into porcine skin in vitro by $6.3 \pm 1.7$-fold $(p<0.01)$ with an approximately 10 -fold $(p<0.01)$ increase in epidermis accumulation of siRNA compared to that from an aqueous solution. Penetration of siRNA was also enhanced at the cellular level. Internalization of SPACE-peptide occurred in a concentration dependent manner marked by a shift in intracellular distribution from punctate spots to diffused cytoplasmic staining at a peptide concentration of $10 \mathrm{mg} / \mathrm{mL}$. In vitro delivery of GAPDH siRNA by SPACE peptide led to $83.3 \pm 3.0 \%$ knockdown relative to the control. In vivo experiments performed using female $\mathrm{BALB} / \mathrm{C}$ mice also confirmed the efficacy of DOTAP-SES in delivering GAPDH-siRNA into skin. Topical application of DOTAP-SES on mice skin resulted in $63.2 \% \pm 7.7 \%$ of GAPDH knockdown, which was significantly higher than that from GAPDH-siRNA PBS $(\mathrm{p}<0.05)$. DOTAP-SES formulation reported here may open new opportunities for cutaneous siRNA delivery.
\end{abstract}

\section{Keywords}

Cell penetrating peptide; Cationic lipids; topical; Silencing; Gene delivery

\footnotetext{
(C) 2014 Elsevier B.V. All rights reserved.

*To whom correspondence should be addressed: Prof. Samir Mitragotri (samir@engineering.ucsb.edu) or Dr. John A. Muraski (jmuraski@convoytx.com).

${ }^{2}$ Current Address, School of Pharmacy, Keck Graduate Institute, 535 Watson Dr., Claremont, CA 91711

a These authors contributed equally to this work.

Publisher's Disclaimer: This is a PDF file of an unedited manuscript that has been accepted for publication. As a service to our customers we are providing this early version of the manuscript. The manuscript will undergo copyediting, typesetting, and review of the resulting proof before it is published in its final citable form. Please note that during the production process errors may be discovered which could affect the content, and all legal disclaimers that apply to the journal pertain.
} 


\section{Introduction}

Since the ability of double-stranded RNA to silence gene expression was discovered in 1998 [1], RNA interference (RNAi) has gained increasing attention as a therapeutic approach for gene-related diseases. The use of short-interfering RNAs (siRNAs) for sequence-specific knockdown of disease-causing genes has led to promising preclinical and clinical studies for a variety of diseases, including cancers, genetic disorders, viral infections and macular degeneration [2-5]. For gene suppression in skin, topical delivery of siRNA offers several benefits including direct access to the target site, reduced adverse effects typically associated with systemic administration, possibility of visual monitoring of the affected region and the possibility of surgical removal of aberrant tissue if unwanted side effects occur $[3,6,7]$.

Topical application of siRNA to treat skin disorders is of particular interest; however, skin is a highly effective defensive barrier designed to protect organisms from the external environment. Generally, only small lipophilic molecules $(<500 \mathrm{Da})$ can penetrate into skin at therapeutically adequate rates [8]. Consequently, delivery of siRNA into skin is very challenging since siRNA is negatively charged, hydrophilic and relatively large ( $13 \mathrm{kDa})$, all of these characteristics lead to poor skin penetration and low absorption into skin's viable cells. As a result, penetration-enhancing technologies are required to improve skin absorption of siRNA so as to reach its therapeutic concentration in the skin, as well as to enhance internalization into the cytoplasm of viable cells. Physical delivery techniques, such as gene gun [9-11], ultrasound [12], intradermal injection [13] and microneedles [14-17], despite their relatively high efficacy, can be applied only to small areas of skin. In addition, some of these methods are invasive and have limited potential for self-administration. In contrast, formulation-based methods offer non-invasive and painless methods and are suitable for large body area application. The nanoparticle systems have shown possibility and efficacy as topical delivery systems for siRNA [18-20]. On the other hand, skin penetrating peptides provide a potential means to improve delivery of siRNA into skin. A variety of peptides such as TAT, polyarginine, meganin, penetratin, TD-1, and SPACEpeptide have been identified enhancing skin delivery of drugs [21-27].

SPACE-Peptide, discovered through phage display, has been shown to deliver siRNA into skin after direct chemical conjugation [25]. Here, in order to further improve the skin absorption of siRNA, we use SPACE-peptide to prepare carriers based on 1, 2-dioleoyl-3trimethylammonium-propane (DOTAP) as a building block [18, 28], referred to as DOTAPSES (DOTAP-based SPACE Ethosomal System) which uses SPACE peptide to enhance the penetration of siRNA into skin in combination with DOTAP-based carriers. We demonstrate the ability of DOTAP-SES to enhance siRNA penetration into skin using GAPDH-siRNA as a model molecule in vitro and in vivo. GAPDH-siRNA was chosen as a model siRNA in this study since GAPDH is a common housekeeping protein and provides an example of a common siRNA target [25, 29]. 


\section{Materials and Methods}

\section{Chemicals}

DOTAP (1, 2-dioleoyl-3-trimethylammonium-propane (chloride salt)) was purchased from Avanti Polar Lipids, Inc. (Alabaster, AL, USA). Phospholipon 90G (Phosphatidylcholine 94.4\%, Lysophophatidylcholine $2.5 \%$, Non-polar lipids $1.5 \%$, tocopherol $0.2 \%$, ethanol $0.1 \%$, water $0.4 \%$ ) was a gift from Lipoid LLC (Newark, NJ, USA). POPE-NHS (COATSOME® FE-6081SU5, N-(Succinimidyloxyglutaryl)- L-aphosphatidylethanolamine, 1-Palmitoyl-2-oleoyl) was purchased from NOF America Corporation (White Plains, NY, USA). SPACE peptide (AC-TGSTQHQ-CG, Disulfide Bridge 2-10) was purchased from Ambiopharm (North Augusta, SC, USA) and Bachem (Torrance, CA, USA). Fluorescein labeled SPACE-peptide (FITC-AC-TGSTQHQ-CG, Disulfide Bridge 2-10) was purchased from RS Synthesis, LLC (Louisville, KY, USA). FAM-Labeled GAPDH-siRNA (5'-FAM-GAC GUA AAC GGC CAC AAG UUC-3') was purchased from Ambion®Life Technologies (Grand Island, NY, USA). Modified FAMGAPDH-siRNA (5'-FAM-GAC GUA AAC GGC CAC AAG UUC N6-3') was purchased from Dharmacon, Thermo Fisher Scientific, Inc. (Waltham, MA, USA). Human adult epidermal keratinocytes and all cell culture materials were acquired from Life Technologies (Grand Island, NY, USA). All other chemicals used in this study were of analytical grade and were purchased from Sigma (St. Louis, MO, USA) or Fisher Scientific (Pittsburgh, PA. USA).

\section{Conjugation of SPACE-Peptide with lipid}

A solution of SPACE peptide (4 mg/) in PBS (pH 8.0) was incubated with a solution of POPE-NHS (4 mg/mL) in ethanol (PBS: ethanol, 1:1, V/V) at room temperature for $2 \mathrm{hrs}$. The efficiency of conjugation of SPACE peptide with POPE-NHS was determined by TNBS (2,4,6-trinitrobenzene sulfonic acid) method [30]. TNBS interacts with primary amino group of peptide to generate a highly chromogenic product, which can be readily measured at 335 $\mathrm{nm}$.

\section{Conjugation of GAPDH-siRNA and SPACE-peptide}

A $10 \mathrm{mM}$ SPACE-peptide solution was incubated with a $10 \mathrm{mM}$ solution of $\mathrm{N}-(3-$ Dimethylaminopropyl)-N'-ethylcarbodiimide hydrochloride (EDAC, Sigma, St. Louis, MO, USA) and a $9.5 \mathrm{mM}$ solution of N-Hydroxysulfosuccinimide sodium salt (NHS, Sigma, St. Louis, MO, USA) in equal parts in MES buffer (pH 5.5) (2-(N-morpholino) ethanesulfonic acid, Sigma, St. Louis, MO, USA) for $15 \mathrm{~min}$. The amine modified GAPDH-siRNA (5'FAM-GAC GUA AAC GGC CAC AAG UUC N6-3' (with FAM labeled) or 5'-GAC GUA AAC GGC CAC AAG UUC N6-3' (without FAM labeled)) was then added to the mixture to conjugate the peptide to siRNA and allowed to mix overnight.

\section{Preparation of ethosomal formulations}

All ethosomal systems were prepared by a conventional rotary evaporation method [31]. Briefly, DOTAP $(10 \mathrm{mg} / \mathrm{mL})$ and cholesterol $(2 \mathrm{mg} / \mathrm{mL})$ in the case of DOTAP-SES or Phospholipon $90 \mathrm{G}(40 \mathrm{mg} / \mathrm{mL})$ in the case of normal ethosomes was dissolved in ethanol. 
The lipid solution was added to SPACE-Peptide-POPE conjugation solution. The solvent was removed using a rotary evaporator at room temperature. Resultant dry lipid films on the inside wall of round bottom flask were hydrated and dispersed with the hydration system (Ethanol/MES buffer, $25 \mathrm{mM}, \mathrm{pH} 4.0,45 \%$, v/v) containing free SPACE-peptide (50 $\mathrm{mg} / \mathrm{mL})$ and GAPDH-siRNA-SPACE conjugate $(25 \mathrm{nmol} / \mathrm{mL})$ or fluorescent probes, including FAM-GAPDH-siRNA $(25 \mathrm{nmol} / \mathrm{mL})$ or FAM-GAPDH-siRNA-SPACE conjugation $(25 \mathrm{nmol} / \mathrm{mL})$, at room temperature. The resultant ethosomal solution was extruded 21 times through a $100 \mathrm{~nm}$ polycarbonate membrane (AVESTIN, Inc., Ottawa, ON, Canada) using a mini-extruder (LiposoFast, AVESTIN, Inc, Ottawa, ON, Canada) at room temperature.

\section{Characterization of ethosomal formulations}

The particle size, polydispersity index (PDI) and $\zeta$-potential of the ethosomal systems were determined by photon correlation spectroscopy (Zetasizer Nano series, Malvern Instruments Ltd., Worcestershire, UK). Before the size and $\zeta$-potential measurements, different ethosomes samples were diluted 100-fold with distilled de-ionized water (EMD Millipore, Billerica, MA, USA). Measurements were made at $25^{\circ} \mathrm{C}$ with a fixed angle of $173^{\circ}$. Sizes quoted here are the $\mathrm{z}$-average means for the ethosomal hydrodynamic diameter. Calculation of $\zeta$-potential $(\mathrm{mV})$ was performed by the instrument from electrophoretic mobility [32].

\section{Skin penetration study in vitro}

Full thickness pig skin (Lampire Biological Laboratories, Pipersville, PA, USA) was used in this study. All skin samples were stored at $-80{ }^{\circ} \mathrm{C}$ and defrosted immediately prior to use. Briefly, the skin was allowed to thaw with the stratum corneum (SC) side up for at least 30 minutes at room temperature. Skin disks of $3.6 \mathrm{~cm}$ diameter were punched out. The subcutaneous fatty tissue was carefully removed from the dermis. The hair shaft was cut off to no more than $4 \mathrm{~mm}$. The skin pieces were cleaned with PBS (pH 7.4) and the integrity of these pieces was determined by measuring the skin conductivity [33] to ensure the samples were free from surface defects. In vitro skin penetration and deposition experiments of different test formulations containing fluorescent probes (FAM-GAPDH-siRNA or FAMGAPDH-siRNA-SPACE conjugation) were performed in Franz diffusion cells (FDCs) under occlusive condition at $37 \pm 1^{\circ} \mathrm{C}$. The effective penetration area and receptor cell volume were $1.77 \mathrm{~cm}^{2}$ and $12.0 \mathrm{~mL}$, respectively. The receptor compartment was filled with PBS at $\mathrm{pH}$ 7.4. Each test formulation was assessed in triplicate. Skin was mounted with the SC side up and the donor compartment was left dry and open to atmosphere for 30 minutes before applying the test formulation. Caution was taken to remove all air bubbles between the underside of the skin (dermis) and the receptor solution. In addition, the skin was stretched in all directions to minimize the presence of furrows. After 30 minutes, $200 \mu \mathrm{L}$ of the test formulation was applied to skin surface using a pipette in the donor compartment. All skin samples on FDCs were incubated for 24 hours at $37{ }^{\circ} \mathrm{C}$ with moderate stirring. At the end of the experiment, a $1 \mathrm{~mL}$ sample was withdrawn from the receptor compartment, and the concentration of fluorescent probe was determined using a micro-plate reader (SAFIRE, XFLUOR4, V4.50, Tecan Group Ltd, Morrisville, NY, USA). The formulations were removed from the skin by washing five times with PBS (pH 7.4). The skin was transferred onto a device for tape-stripping the SC.

J Control Release. Author manuscript; available in PMC 2015 May 09. 


\section{Extraction of Fluorescent probes from skin layers}

The SC was removed by stripping with an adhesive tape (Scotch® Transparent Tape, 3M Corporate, St. Paul, MN, USA). In order to avoid impact of furrows, the skin was stretched and mounted on cork discs. The skin was covered with a Teflon mask with a central hole of $15 \mathrm{~mm}$ in diameter. Each tape was put onto the skin and a weight of $2 \mathrm{~kg}$ was placed on the tape for 10 seconds. The tape was quickly removed with forceps and transferred into a glass vial of suitable size. Ten stripping procedures were performed consecutively. The stripped tapes were collected in glass vials according to the following scheme: vial $1=1^{\text {st }}$ strip, vial $2=2^{\text {nd }}-5^{\text {th }}$ strips and vial $3=6^{\text {th }}-10^{\text {th }}$ strips. After tape-stripping, the epidermis sheet was separated from the dermis with a surgical sterile scalpel and cut into small pieces and collected into a glass vial. The dermis was cut into small pieces and transferred into a glass vial. For extraction of fluorescent probes from the separated skin layers, $4 \mathrm{~mL}$ of methanol and PBS pH 7.4 (1:1, v/v) mixture was added to each glass vial, and the vials were shaken overnight at room temperature. Afterwards the dispersions were centrifuged (10 minutes, $10000 \mathrm{rpm}$ ) to pellet skin tissue pieces at the bottom. The supernatants were withdrawn, diluted if necessary, and concentrations of fluorescent probes were determined by fluorescence spectroscopy. Fluorescence detection was performed at an excitation of $485 \mathrm{~nm}$ and an emission of $520 \mathrm{~nm}$. The method was validated for linearity, accuracy and precision. The linear range during the measurements was from $0.25 \mathrm{pmol} / \mathrm{mL}$ to $25 \mathrm{pmol} / \mathrm{mL}$ $\left(r^{2}=0.9999\right)$ in the both cases of FAM-GAPDH-siRNA and FAM-GAPDH-siRNA-SPACEPeptide.

\section{Cell culturing conditions}

Human adult epidermal keratinocytes were cultured in EpiLife Medium supplemented with Human Keratinocyte Growth Supplement, $50 \mathrm{U} / \mathrm{mL}$ penicillin, $50 \mu \mathrm{g} / \mathrm{mL}$ streptomycin, and $100 \mu \mathrm{g} / \mathrm{mL}$ neomycin. Cultures were grown at $37{ }^{\circ} \mathrm{C}$ with $5 \% \mathrm{CO}_{2}$.

\section{Cell internalization in vitro}

10,000 cells were seeded on poly-d-lysine-coated glass bottom culture dishes (MatTek Corporation, Ashland, MA, USA) and were allowed to attach and proliferate for $24 \mathrm{hrs}$ under standard culture conditions $\left(37^{\circ} \mathrm{C}\right.$ with $\left.5 \% \mathrm{CO}_{2}\right)$. After incubation at $37^{\circ} \mathrm{C}$ for 24 hrs, the media was removed and $50 \mu \mathrm{L}$ of fluorescent peptide solution in culture media was added to the cell culture dish. Alternatively, fluorescent peptide solution co-incubated with non-fluorescent peptide was used to study the effect of free SPACE peptide. As a control, an equivalent amount of media was added in place of a peptide solution. Cell cultures were incubated for $120 \mathrm{~min}$ or $30 \mathrm{~min}$ for internalization studies and $15 \mathrm{~min}$ for free SPACE studies, after which the fluorescent solution was removed and cells were prepared for confocal microscopy.

\section{Confocal Microscopy}

After incubation with fluorescent peptide solution, cells were incubated with $5 \mu \mathrm{g} / \mathrm{mL}$ Hoechst 33342 (Life Technologies, Grand Island, NY, USA) for 5 minutes at room temperature and then washed with supplemented Hank's Balanced Salt Solution (HBSS, Lonza Group Ltd., Basel, Switzerland). HBSS was supplemented with $200 \mu \mathrm{M}$ Trolox 
(Sigma, St. Louis, MO, USA) to limit phototoxicity and photobleaching during imaging. Cells were washed with supplemented HBSS 3 times for 5 minutes each. The cell culture dishes were then filled with $90 \mu \mathrm{M}$ Ethidium Bromide in supplemented HBSS and imaged using a confocal laser scanning microscope (Olympus Fluoview 1000S, Olympus, Center Valley, PA). $90 \mu \mathrm{M}$ Ethidium Bromide was sufficient to quench any significant fluorescence from externally-bound FITC-SPACE peptide. Image analysis was performed using Image J (NIH, Bethesda, MD, USA) to determine the overall fluorescence intensity for each cell. All instrument settings were kept constant for any comparisons between experimental conditions and a 30X silicon immersion objective was used to capture the entire thickness of the cell. Dead cells indicated by Ethidium Bromide staining of the nucleus were ignored during analysis.

\section{Cytotoxicity of SPACE peptide}

The cytotoxicity of SPACE peptide was determined using the MTT Cell Proliferation Assay (ATCC, Manassas, VA, USA). Cells were incubated with $1 \mathrm{mg} / \mathrm{mL}$ or $10 \mathrm{mg} / \mathrm{mL}$ unconjugated SPACE peptide in media for $30 \mathrm{~min}, 60 \mathrm{~min}$, or $120 \mathrm{~min}$. Cells incubated with media only was used as a control. Viability was determined according to the manufacturer's recommended protocol using a SAFIRE, XFLUOR4, V4.50 micro-plate reader (Tecan Group Ltd, Morrisville, NY, USA).

\section{GAPDH knockdown in vitro}

10,000 cells/well were seeded in 96-well microplates (Corning Inc., Corning, NY, USA) and allowed to attach overnight. The cells were then incubated with $50 \mu \mathrm{L}$ of $1 \mu \mathrm{M}$ GAPDH siRNA, $10 \mathrm{mg} / \mathrm{mL}$ SPACE peptide, or $1 \mu \mathrm{M}$ GAPDH-SPACE peptide co-incubated with 10 $\mathrm{mg} / \mathrm{mL}$ unconjugated SPACE peptide. All test conditions were prepared in supplemented media and knockdown was normalized to a control condition of media alone. All test solutions were applied for 30 min every $12 \mathrm{hrs}$. After $72 \mathrm{hrs}$, the total protein concentration in each well was determined using the Bicinchoninic Acid Protein Assay Kit (Thermo Scientific, Rockford, IL, USA) and GAPDH levels were measured using the KDalert GAPDH Assay Kit (Life Technologies, Grand Island, NY, USA).

\section{Skin penetration in vivo}

The efficacy of DOTAP-SES in inducing knockdown of GAPDH protein in female BALB/c mice (Charles River Laboratories, 8 weeks old) was tested according to protocols approved by the Institutional Animal Care and Use Committee (IACUC). Briefly, the animals were anesthetized using isoflurane inhalation (2-3\%), the back skin of animals was shaved, and a cylinder with an exposed skin area of $1.8 \mathrm{~cm}^{2}$ was attached to the back of anesthetized animals using minimal Vetbond ${ }^{\circledR}$ tissue glue (3M Corporation, St Paul, MN, USA). $200 \mu \mathrm{L}$ of the test solution was topically applied in the attached cylinder, and was manually spread over the entire exposure area. Applied test solutions were allowed to incubate with the exposed skin for 6 hours while keeping animals under minimal anesthesia. After 6 hours, the cylinder was carefully removed, and the entire exposure area was covered with sterile gauze and a breathable bandage. During the entire duration of experiments, animals were closely monitored for vital parameters. After $72 \mathrm{hrs,} \mathrm{animals} \mathrm{were} \mathrm{sacrificed} \mathrm{with} \mathrm{CO}_{2}$ overexposure, and skin biopsies ( $5 \mathrm{~mm}$ diameter) were collected from treated area of the 
animal's skin. Total protein concentration in the skin biopsy tissue was determined using the Micro BCA Protein Assay Kit (Thermo Scientific, Rockford, IL, USA) and GAPDH levels were measured using the KDalert GAPDH Assay Kit (Life Technologies, Grand Island, NY, USA)

\section{Data analysis}

Data reported for skin and cell penetration in vitro are mean \pm SD. Data reported for GAPDH knockdown both in vitro and in vivo are mean \pm SE. Statistical significance was confirmed by the two-tailed and unpaired Student's t-test in Microsoft Excel. The level of significance was set at $p<0.05$, unless otherwise indicated.

\section{Results}

\section{In vitro penetration of siRNA into porcine skin}

The key formulation described here is a suspension of SPACE-peptide-decorated cationic ethosomes (i.e., DOTAP-SPACE Ethosomal System or DOTAP-SES). The formulation contains SPACE-conjugated siRNA encapsulated in a carrier made up of a cationic lipid (DOTAP), a lipid membrane stabilizer (cholesterol), SPACE-conjugated lipids (SPACEpeptide-POPE), free SPACE-peptide $(50 \mathrm{mg} / \mathrm{mL}$ ), all suspended in an ethanolic buffer ( $45 \%$ $\mathrm{v} / \mathrm{v})$. SPACE peptide is present at three places: direct conjugation to siRNA, direct conjugation to ethosomal particle surface and free form. The efficiency of conjugation between SPACE-peptide and POPE-NHS was more than 90\%. Unconjugated SPACEpeptide was kept in the DOTAP-SES formulations.

DOTAP-SES possessed a mean particle diameter of $108.4 \pm 3.4 \mathrm{~nm}$ with a low polydispersity index (PDI) of $0.095 \pm 0.003$, and a positive surface charge of $49.1 \pm 0.6 \mathrm{mV}$. DOTAP-SES significantly enhanced skin penetration of GAPDH-siRNA compared to aqueous solutions of the same siRNA $(p<0.01)$ (Fig. 2a). DOTAP-SES led to dermal penetration of $18.5 \%$ $\pm 3.3 \%$ of topically applied siRNA, which was $6.3 \pm 1.7$-fold $(p<0.01)$ higher than siRNA penetration from an aqueous solution $(p<0.01)$. DOTAP-SES also increased the accumulation of siRNA in viable epidermis; $4.7 \% \pm 0.2 \%$ of the applied dose penetrated into the epidermis, which is approximately 10 -fold $(p<0.01)$ higher than that from the water solution (Fig. 2a). Detailed penetration profile of siRNA from DOTAP-SES and water can be seen in Fig. 2b.

The role of various components of DOTAP-SES in skin penetration was studied (Fig. 3). Removal of SPACE peptide from the siRNA-SPACE conjugate, while keeping SPACE peptide on lipids and in the free form (DOTAP-SES with unconjugated siRNA formulation), led to significant reduction of skin penetration compared to DOTAP-SES formulation, thus confirming that direct conjugation to siRNA brings benefits in enhancing skin penetration (bars 1 vs. 2, Fig 3). Note, however, that siRNA penetration from this formulation was still significantly higher than that from a simple aqueous solution. Charge on the lipids also had a significant impact on efficacy. Replacement of DOTAP (zeta potential $49.1 \pm 0.6 \mathrm{mV}$ ) with POPE (zeta potential: $-47.7 \mathrm{mV} \pm 0.8 \mathrm{mV}$ and diameter: $92.9 \mathrm{~nm} \pm 2.7 \mathrm{~nm}$ ) dramatically reduced skin penetration (bars 1 vs. 3, Fig 3). DOTAP-SES without SPACE peptide, in free 
or conjugated form, also exhibited lower penetration compared to DOTAP-SES (bars 1 vs. 4, Fig 3). This formulation (bar 4, Fig 3), however, did exhibit higher penetration into skin compared to aqueous solution of siRNA indicating the benefit of cationic lipids in enhancing siRNA skin penetration. The penetration induced by this formulation, however, was superficial and minimal penetration into epidermis was seen. SPACE-conjugated siRNA without ethosomes also exhibited significant penetration and increased epidermal penetration was seen (bar 5, Fig. 3) indicating the benefits of SPACE peptide in enhancing skin permeability.

\section{Penetration and Localization of SPACE peptide in Cells}

The ability of SPACE peptide to enter cells and enhance penetration of siRNA into keratinocytes in vitro was assessed. These experiments were performed using free SPACE peptide and SPACE-siRNA conjugates since ethanol in SES formulations precludes their direct placement on cells in culture. Cells incubated with FITC-labeled SPACE peptide exhibited a concentration-dependent cell entry (Fig. 4a,b). Cell entry was observed at short times (30 minutes, Fig. 4a) and depended on the concentration (120 minutes, Fig. 4b). A clear transition in cell entry was observed at a concentration between $4 \mathrm{mg} / \mathrm{mL}$ and 10 $\mathrm{mg} / \mathrm{mL}$. Internalization of SPACE peptide at $10 \mathrm{mg} / \mathrm{mL}$ was approximately 4-fold higher compared to that at $4 \mathrm{mg} / \mathrm{mL}(3.7 \pm 1.0$ and $5.7 \pm 1.5$ for $30 \mathrm{~min}$ and 120 min incubations, respectively) (Figs. 4a,b). There was a clear transition in the distribution pattern of SPACE peptide within the cells at the same concentration. After incubation at concentrations of 1-4 $\mathrm{mg} / \mathrm{mL}$, FITC-SPACE peptide localized likely in endosomal structures as suggested by the presence of punctate fluorescent spots (Fig. 4c,i,ii). At higher concentrations, however a significant portion of the fluorescence was diffused throughout the cytoplasm (Fig. 4ciii, iv), suggesting endosomal escape or cell entry without endocytosis at higher concentrations.

No significant toxicity associated with SPACE peptide was observed in this concentration range for $30 \mathrm{~min}$ and $60 \mathrm{~min}$ incubations (Fig. 5). Slight toxicity was noted for longer incubation times; however, there is no significant difference in toxicity between $1 \mathrm{mg} / \mathrm{mL}$ and $10 \mathrm{mg} / \mathrm{mL}$ SPACE peptide (Fig. 5).

To clearly assess the effect of free SPACE peptide on its internalization and/or endosomal escape, cells were incubated with trace amount of FITC-SPACE peptide $(0.1 \mathrm{mg} / \mathrm{mL})$ with or without $10 \mathrm{mg} / \mathrm{mL}$ unlabeled SPACE peptide. Addition of free SPACE peptide increased

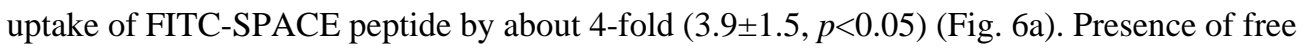
SPACE peptide also impacted localization of FITC-SPACE peptide. In the absence of excess free SPACE peptide, FITC-SPACE peptide localized primarily in punctate spots (Fig. 6b) whereas addition of $10 \mathrm{mg} / \mathrm{mL}$ SPACE peptide induced cytoplasmic localization (Fig. 6c).

\section{Delivery of siRNA into keratinocytes using SPACE peptide}

The ability of SPACE-peptide to facilitate internalization of GAPDH siRNA was verified (Fig. 7). GAPDH siRNA conjugated to SPACE peptide and co-incubated with $10 \mathrm{mg} / \mathrm{mL}$ free SPACE peptide resulted in $83.3 \pm 3.0 \%$ knockdown relative to the control. Moreover, 
knockdown for the test group was significantly higher $(p<0.01)$ compared to siRNA alone $(15.6 \pm 6.8 \%)$ and $10 \mathrm{mg} / \mathrm{mL}$ SPACE peptide alone $(28.5 \pm 14.1 \%)$.

\section{In vivo verification of GAPDH siRNA delivery}

The ability of DOTAP-SES to deliver GAPDH siRNA into skin was assessed using female BALB/C mice in vivo. Topical application of DOTAP-SES on mice skin for $72 \mathrm{hrs}$ resulted in $63.2 \% \pm 7.7 \%$ of GAPDH knockdown, which is significantly higher than that from GAPDH-siRNA PBS (pH 8.0) $(20.2 \% \pm 12.3 \%, p<0.05)$ or that from blank DOTAP-SES formulation $(21.0 \% \pm 5.8 \%, p<0.05)$ (Fig 8$)$. CD44 siRNA was used as a negative siRNA control and no significant effect of CD44 siRNA on skin GAPDH concentrations was observed ( $p>0.2$ ), indicating that GAPDH knockdown from the test formulations containing GAPDH-siRNA is GAPDH-gene specific.

\section{Stability of DOTAP-SES}

Physical stability of the DOTAP-SES formulation was investigated at $4{ }^{\circ} \mathrm{C}$ in one week in terms of particle size distribution (Fig. 9a,b) and $\zeta$-potential (Fig. 9c). The particle size distribution and $\zeta$-potential of the system changed slightly in one week (from 111.0 $\pm 1.8 \mathrm{~nm}$ to $121.7 \pm 0.5 \mathrm{~nm}$ and from $53.6 \pm 0.8 \mathrm{mV}$ to $55.9 \pm 0.6 \mathrm{mV}$, respectively). Moreover, the formulation exhibited low polydispersity index (PDI) values (PDI $\sim 0.2$ ), indicating that it was a homogeneous suspension.

\section{Discussion}

The peptide penetration enhancer used in this study, SPACE-peptide, has been reported to overcome the skin barrier posed by the stratum corneum and to deliver siRNA deep into skin layers, when conjugated with its cargo [25] and also in the form of ethosomal system [34].

SPACE-peptide also exhibited increased penetration into various cell-lines including keratinocytes, fibroblasts, and Human Umbilical Vein endothelial cells. In this study, the skin absorption of GAPDH-siRNA, when conjugated with SPACE-peptide, was significantly increased in vitro $(5.1 \% \pm 0.7 \%, p<0.05)$ compared to those from the naked GAPDH-siRNA in water solution or in MES buffer ( $\mathrm{pH}$ 5.5) solution. These results confirmed the ability of SPACE peptide to enhance siRNA penetration into skin. Skin penetration of siRNA was further improved by incorporation of DOTAP ethosomes and free excess SPACE peptide in the formulation.

Lipid-based nanoparticles have been used to deliver nucleic acids into skin for around two decades [35-38]. Major advantages of using liposomes include their ability to protect siRNAs from degradation and the possibility of receptor-mediated targeting [39]. In this study, anionic SPACE-ethosomal system, which consists primarily of phospholipon 90G $(40 \mathrm{mg} / \mathrm{mL})$ and used for Hyaluronic acid skin delivery [34], with containing free SPACE was not found to be capable of enhancing the skin absorption of GAPDH-siRNA in vitro $(1.8 \% \pm 0.1 \%)$ compared to its water solution or MES buffer solution $(p>0.05)$. In contrast, cationic SPACE-DOTAP-ethosomal system containing free SPACE-peptide (DOTAP-SES) significantly increased the skin accumulation of GAPDH-siRNA in vitro $(18.5 \% \pm 3.3 \%$, $p<0.01)$. This suggested that the mechanism by which SES formulation increased the 
penetration of HA is quite different from the mechanism by which DOTAP-SES formulation enhanced the absorption of siRNA. Due to its positive electrical charge on the head group, DOTAP is often used for formulating lipid vesicles [18, 20,40-44] to complex with negatively charged nucleic acids, protecting the genetic material from degradation and enhancing the transfection efficiency [45]. Consequently, GAPDH-siRNA can bind to or interact with DOTAP ethosomal particles to form complexes by electrostatic interactions while DOTAP ethosomal vesicles can penetrate into skin deep layers with bringing bound, encapsulated and associated siRNA. Previous studies with DOTAP-based ethosomes have indicated that the majority of the siRNA molecules were not just bound to the outer surface of the vesicles but rather "sandwiched" in between cationic lipid multilamellar layers so that the siRNA could be protected from shear forces and enzyme degradation during its skin penetration [8]. Studies reported in Fig. 3 indicate that the overall penetration of siRNA from DOTAP-SES is a result of synergistic effect of various contributions including SPACE-siRNA conjugation, SPACE-DOTAP ethosomes and free SPACE peptide.

DOTAP-SES formulation (containing 45\% ethanol, v/v, $\mathrm{pH} 4.0$ ) showed acceptable stability. Based on the previous literature reports [46-51], 45\% v/v ethanol was often chosen as an optimal ethanol concentration in ethosomes and then used to prepare DOTAP-SES formulations. High concentration of ethanol in the formulation can provide flexible characteristics to the vesicles and it also effectively disrupts lipid bilayers structure of the skin with resulting in an increase in the membrane permeability. The long term stability of DOTAP-SES formulation needs further investigation. Further, detailed studies on the role of ethanol in formulation and its effect of lipid bilayers and SPACE-peptide are interesting and need to be performed in future. The $\mathrm{pH}$ value of DOTAP-SES formulation was chosen to be 4 since the formulation was found to be more stable against aggregation at this $\mathrm{pH}$. The precise reasons for this observation are not clear and need further investigation. However, the $\mathrm{pH}$ value of solvent does not affect the skin penetration of siRNA itself since there is no significant difference between skin penetrations of siRNA from its water solution or MES buffer (pH 5.5) (p>0.05, Figure 1).

Once inside the skin, the siRNA must be able to enter into cells, primarily keratinocytes. Similar to the stratum corneum, the cell membrane poses a significant barrier to the delivery of siRNA [46]. Several strategies have been employed in the literature to overcome this limitation including the use of electroporation [47], heat-shock [48], and chemical methods [49-52]. Alternatively, cell-penetrating peptides (CPPs) represent an appealing delivery system due to their simplicity and diversity. CPPs have been successfully applied for the delivery of a variety of molecules including methotrexate, Survivin, and gold nanoparticles [53]. However, CPPs are generally internalized predominantly via endocytotic pathways [54-56] which results in their sequestration in endosomal and lysosomal compartments. For CPPs where macropinocytosis is the dominant internalization pathway (e.g. TAT and polyarginine) [57-59], leakage from macropinosomes into the cytoplasm and avoidance of lysosomal degradation is possible $[60,61]$; however, the likelihood of macropinosomal escape is inefficient at best for large macromolecules like siRNA. High concentration of CPPs are often required to achieve sufficient cytoplasmic concentrations, however, high concentrations of cationic and amphipathic CPPs are often toxic to cells [62, 63]. 
Owing to its neutral charge, SPACE peptide, is non-toxic at concentrations studied here. For longer incubation times, SPACE peptide is only slightly toxic and no significant difference was observed in toxicity between $1 \mathrm{mg} / \mathrm{mL}$ and $10 \mathrm{mg} / \mathrm{mL}$ ( $p>0.50$ ). SPACE peptide exhibited a concentration-dependent internalization and intracellular localization. Higher concentrations exhibited a shift in intracellular distribution from predominantly endocytotic vesicles to diffused cytoplasmic. Free SPACE peptide also enhanced internalization of SPACE-conjugated siRNA and led to higher knockdown $(83.3 \pm 3.0 \%)$ relative to the control. This knockdown for the test group was significantly higher $(p<0.01)$ compared to siRNA alone $(15.6 \pm 6.8 \%)$ and $10 \mathrm{mg} / \mathrm{mL}$ SPACE peptide alone $(28.5 \pm 14.1 \%)$.

Together, the data confirm the ability of SPACE peptide to enhance the internalization and cytoplasmic localization. Additionally, the results suggest that SPACE peptide may signal a change from predominantly internalized via macropinocytosis at high concentrations [25]. This shift in localization may be a result of increased endosomal escape, or SPACE peptide may be internalized by an alternative pathway at high concentrations. Therefore, a local SPACE peptide concentration above $4 \mathrm{mg} / \mathrm{mL}$ in diseased tissue would be ideal for maximizing the delivery of siRNA into the cytoplasm and minimizing loss to intracellular sequestration and lysozomal degradation. While the distribution of free SPACE peptide in skin layers is not clear at this time, it is expected to be equal or better for the free peptide compared to that for the peptide attached to cargo. The results presented here as well as previously [34], combined with the ease of applying high concentration doses topically, suggest achieving concentrations upwards of $4 \mathrm{mg} / \mathrm{mL}$ in the skin is feasible.

In vivo results confirmed efficacy of DOTAP-SES in siRNA delivery. The ability of SPACE peptide to enhance siRNA delivery into skin may open new opportunities for the treatment of dermatological diseases. RNA interference applies particularly to monogenic dominant negative skin diseases where the silencing of a specific disease-causing gene is expected to have a clinical effect [3] . Further, since it can be designed to target any given gene mutation, siRNA therapeutics are promising for personalized medicine. In addition, A variety of skin disorders are potential targets for siRNA delivery. These include (i) hyperproliferating states such as psoriasis, epidermal hyperplasia and hyperkeratosis, (ii)skin cancer including basal cell carcinoma and melanoma, and (iii) inflammatory diseases including atopic dermatitis and alopecia, among others. Moreover, more than 80 distinct genes have been found to be involved in more than 100 heritable skin disease phenotypes [64], many of which are currently without effective treatment options. These dermatological diseases represent an exciting target for siRNA delivery owing to the localized nature of the disease and the ability to place the formulation in close proximity to target cells. However, the use of siRNA therapeutics for dermatological diseases is limited by delivery challenges. The studies reported here offer a new tool to address this challenge and may open new opportunities for siRNA delivery to skin.

\section{Conclusion}

The study demonstrates improved penetration of siRNA into skin and enhanced internalization into epidermal keratinocytes due to a SPACE-peptide-decorated cationic ethosomal system, DOTAP-SES. The inclusion of SPACE peptide at each of the three 
places in the system (direct conjugation to siRNA, direct conjugation to ethosomal particle surface, and free form) all contributed to the enhanced skin delivery of siRNA. Additionally, direct conjugation to siRNA together with free form SPACE-peptide resulted in enhanced delivery into the cytoplasm of epidermal keratinocytes and effective gene silencing in vitro. The efficacy of DOTAP-SES to deliver siRNA into skin and elicit gene silencing was also confirmed by in vivo experiments. In addition, DOTAP-SES formulation was found to be stable for at least one week. This novel formulation has the potential to be developed further as a non-invasive siRNA topical delivery system.

\section{Acknowledgements}

This work was supported by Convoy Therapeutics Inc. A.C.A. was supported by a National Science Foundation (NSF) Graduate Research Fellowship under Grant DGE-1144085. We thank the NRI-MCDB Microscopy Facility for access to the Olympus Fluoview 1000 Spectral confocal microscope, which was supported by NIH Grant 1 S10 OD010610-01A1. SM is a shareholder and scientific advisor to Convoy Therapeutics.

\section{Reference}

1. Fire A, Xu SQ, Montgomery MK, Kostas SA, Driver SE, Mello CC. Potent and specific genetic interference by double-stranded RNA in Caenorhabditis elegans. Nature. 1998; 391:806-811. [PubMed: 9486653]

2. Aigner A. Gene silencing through RNA interference (RNAi) in vivo: Strategies based on the direct application of siRNAs. J Biotechnol. 2006; 124:12-25. [PubMed: 16413079]

3. Geusens B, Sanders N, Prow T, Van Gele M, Lambert J. Cutaneous short-interfering RNA therapy. Expert Opin Drug Del. 2009; 6:1333-1349.

4. Rayburn ER, Zhang RW. Antisense, RNAi, and gene silencing strategies for therapy: Mission possible or impossible? Drug Discov Today. 2008; 13:513-521. [PubMed: 18549978]

5. Morrissey DV, Lockridge JA, Shaw L, Blanchard K, Jensen K, Breen W, Hartsough K, Machemer L, Radka S, Jadhav V, Vaish N, Zinnen S, Vargeese C, Bowman K, Shaffer CS, Jeffs LB, Judge A, MacLachlan I, Polisky B. Potent and persistent in vivo anti-HBV activity of chemically modified siRNAs. Nat Biotechnol. 2005; 23:1002-1007. [PubMed: 16041363]

6. Khavari PA, Rollman O, Vahlquist A. Cutaneous gene transfer for skin and systemic diseases. J Intern Med. 2002; 252:1-10. [PubMed: 12074732]

7. Fattal E, Bochota A. State of the art and perspectives for the delivery of antisense oligonucleotides and siRNA by polymeric nanocarriers. Int J Pharmaceut. 2008; 364:237-248.

8. Bos JD, Meinardi MMHM. The 500 Dalton rule for the skin penetration of chemical compounds and drugs. Exp Dermatol. 2000; 9:165-169. [PubMed: 10839713]

9. Peachman KK, Rao M, Alving CR. Immunization with DNA through the skin. Methods. 2003; 31:232-242. [PubMed: 14511956]

10. Liu Y, Truong NK, Kendall MAF, Bellhouse BJ. Characteristics of a micro-biolistic system for murine immunological studies. Biomed Microdevices. 2007; 9:465-474. [PubMed: 17484054]

11. Dileo J, Miller TE, Chesnoy S, Huang L. Gene transfer to subdermal tissues via a new gene gun design. Hum Gene Ther. 2003; 14:79-87. [PubMed: 12573061]

12. Rao R, Nanda S. Sonophoresis: recent advancements and future trends. J Pharm Pharmacol. 2009; 61:689-705. [PubMed: 19505359]

13. Hengge UR, Chan EF, Foster RA, Walker PS, Vogel JC. Cytokine Gene-Expression in Epidermis with Biological Effects Following Injection of Naked DNA. Nat Genet. 1995; 10:161-166. [PubMed: 7545056]

14. Coulman S, Allender C, Birchall J. Microneedles and other physical methods for overcoming the stratum corneum barrier for cutaneous gene therapy. Crit Rev Ther Drug. 2006; 23:205-258. 
15. Pearton M, Allender C, Brain K, Anstey A, Gateley C, Wilke N, Morrissey A, Birchall J. Gene delivery to the epidermal cells of human skin explants using microfabricated microneedles and hydrogel formulations. Pharmaceutical Research. 2008; 25:407-416. [PubMed: 17671832]

16. McAllister DV, Allen MG, Prausnitz MR. Microfabricated microneedles for gene and drug delivery. Annu Rev Biomed Eng. 2000; 2:289-313. [PubMed: 11701514]

17. Chabri F, Bouris K, Jones T, Barrow D, Hann A, Allender C, Brain K, Birchall J. Microfabricated silicon microneedles for nonviral cutaneous gene delivery. Br J Dermatol. 2004; 150:869-877. [PubMed: 15149498]

18. Geusens B, Van Gele M, Braat S, De Smedt SC, Stuart MCA, Prow TW, Sanchez W, Roberts MS, Sanders NN, Lambert J. Flexible Nanosomes (SECosomes) Enable Efficient siRNA Delivery in Cultured Primary Skin Cells and in the Viable Epidermis of Ex Vivo Human Skin. Adv Funct Mater. 2010; 20:4077-4090.

19. Desai PR, Marepally S, Patel AR, Voshavar C, Chaudhuri A, Singh M. Topical delivery of antiTNFalpha siRNA and capsaicin via novel lipid-polymer hybrid nanoparticles efficiently inhibits skin inflammation in vivo. J Control Release. 2013; 170:51-63. [PubMed: 23643662]

20. Zheng D, Giljohann DA, Chen DL, Massich MD, Wang XQ, Iordanov H, Mirkin CA, Paller AS. Topical delivery of siRNA-based spherical nucleic acid nanoparticle conjugates for gene regulation. P Natl Acad Sci USA. 2012; 109:11975-11980.

21. Kamada H, Okamota T, Kawamura M, Shibata H, Abe Y, Ohkawa A, Nomura T, Sato M, Mukai Y, Sugita T, Imai S, Nagano K, Tsutsumi Y, Nakagawa S, Mayumi T, Tsunoda S. Creation of novel cell-penetrating peptides for intracellular drug delivery using systematic phage display technology originated from tat transduction domain. Biol Pharm Bull. 2007; 30:218-223. [PubMed: 17268054]

22. Kim YC, Ludovice PJ, Prausnitz MR. Transdermal delivery enhanced by magainin pore-forming peptide. J Control Release. 2007; 122:375-383. [PubMed: 17628164]

23. Rothbard JB, Garlington S, Lin Q, Kirschberg T, Kreider E, McGrane PL, Wender PA, Khavari PA. Conjugation of arginine oligomers to cyclosporin A facilitates topical delivery and inhibition of inflammation. Nat Med. 2000; 6:1253-1257. [PubMed: 11062537]

24. Sawant R, Torchilin V. Intracellular transduction using cell-penetrating peptides. Mol Biosyst. 2010; 6:628-640. [PubMed: 20237640]

25. Hsu T, Mitragotri S. Delivery of siRNA and other macromolecules into skin and cells using a peptide enhancer. P Natl Acad Sci USA. 2011; 108:15816-15821.

26. Chen YP, Shen YY, Guo X, Zhang CS, Yang WJ, Ma ML, Liu S, Zhang MB, Wen LP. Transdermal protein delivery by a coadministered peptide identified via phage display. Nat Biotechnol. 2006; 24:455-460. [PubMed: 16565728]

27. Yi XA, Zhao GA, Zhang HJ, Guan D, Meng RS, Zhang YY, Yang QQ, Jia HM, Dou KJ, Liu C, Que FY, Yin JQ. MITF-siRNA Formulation Is a Safe and Effective Therapy for Human Melasma. Mol Ther. 2011; 19:362-371. [PubMed: 21119619]

28. Kim A, Lee EH, Choi SH, Kim CK. In vitro and in vivo transfection efficiency of a novel ultradeforinable cationic liposome. Biomaterials. 2004; 25:305-313. [PubMed: 14585718]

29. Bonoiu AC, Bergey EJ, Ding H, Hu R, Kumar R, Yong KT, Prasad PN, Mahajan S, Picchione KE, Bhattacharjee A, Ignatowski TA. Gold nanorod-siRNA induces efficient in vivo gene silencing in the rat hippocampus. Nanomedicine-Uk. 2011; 6:617-630.

30. Goodwin JF, Choi SY. Quantification of Protein Solutions with Trinitrobenzenesulfonic Acid. Clin Chem. 1970; 16 24-\&.

31. Bendas ER, Tadros MI. Enhanced Transdermal Delivery of Salbutamol Sulfate via Ethosomes. Aaps Pharmscitech. 2007; 8

32. Nanda A NS, Khan Ghilzai NM. Current developments using emerging transdermal technologies in physical enhancement methods. Current Drug Delivery. 2006; 3:233-242. [PubMed: 16848725]

33. Karande P, Jain A, Mitragotri S. Relationships between skin's electrical impedance and permeability in the presence of chemical enhancers. J Control Release. 2006; 110:307-313. [PubMed: 16313994] 
34. Chen M, Gupta V, Anselmo AC, Muraski JA, Mitragotri S. Topical delivery of hyaluronic acid into skin using SPACE-peptide carriers. J Control Release. 2013; 173C:67-74. [PubMed: 24129342]

35. Lee EH, Kim A, Oh YK, Kim CK. Effect of edge activators on the formation and transfection efficiency of ultradeformable liposomes. Biomaterials. 2005; 26:205-210. [PubMed: 15207467]

36. Alexander MY, Akhurst RJ. Liposome-medicated gene transfer and expression via the skin. Hum Mol Genet. 1995; 4:2279-2285. [PubMed: 8634699]

37. Niemiec SM, Latta JM, Ramachandran C, Weiner ND, Roessler BJ. Perifollicular transgenic expression of human interleukin-1 receptor antagonist protein following topical application of novel liposome-plasmid DNA formulations in vivo. J Pharm Sci. 1997; 86:701-708. [PubMed: 9188052]

38. Babiuk S, Baca-Estrada ME, Pontarollo R, Foldvari M. Topical delivery of plasmid DNA using biphasic lipid vesicles (Biphasix). J Pharm Pharmacol. 2002; 54:1609-1614. [PubMed: 12542889]

39. Yu B, Zhao XB, Lee LJ, Lee RJ. Targeted Delivery Systems for Oligonucleotide Therapeutics. Aaps J. 2009; 11:195-203. [PubMed: 19296227]

40. Leonenko ZV, Merkle D, Lees-Miller SP, Cramb DT. Lipid phase dependence of DNA-cationic phospholipid bilayer interactions examined using atomic force microscopy. Langmuir. 2002; 18:4873-4884.

41. Campbell RB, Balasubramanian SV, Straubinger RM. Phospholipid-cationic lipid interactions: influences on membrane and vesicle properties. Bba-Biomembranes. 2001; 1512:27-39. [PubMed: 11334622]

42. Campbell RB, Balasubramanian SV, Straubinger RM. Biophysical characterization of cationic lipid - Phospholipid interactions. Biophys J. 1999; 76:A55-A55.

43. Stamatatos L, Leventis R, Zuckermann MJ, Silvius JR. Interactions of Cationic Lipid Vesicles with Negatively Charged Phospholipid-Vesicles and Biological-Membranes. Biochemistry. 1988; 27:3917-3925. [PubMed: 3415963]

44. Zabner J. Cationic lipids used in gene transfer. Advanced drug delivery reviews. 1997; 27:17-28. [PubMed: 10837548]

45. Kim A, Lee EH, Choi SH, Kim CK. In vitro and in vivo transfection efficiency of a novel ultradeformable cationic liposome. Biomaterials. 2004; 25:305-313. [PubMed: 14585718]

46. Rajendran L, Knolker HJ, Simons K. Subcellular targeting strategies for drug design and delivery. Nature reviews. Drug discovery. 2010; 9:29-42.

47. Neumann E, Schaeferridder M, Wang Y, Hofschneider PH. GENE-TRANSFER INTO MOUSE LYOMA CELLS BY ELECTROPORATION IN HIGH ELECTRIC-FIELDS. Embo Journal. 1982; 1:841-845. [PubMed: 6329708]

48. van der Rest ME, Lange C, Molenaar D. A heat shock following electroporation induces highly efficient transformation of Corynebacterium glutamicum with xenogeneic plasmid DNA. Applied Microbiology and Biotechnology. 1999; 52:541-545. [PubMed: 10570802]

49. Aigner A. Delivery systems for the direct application of siRNAs to induce RNA interference (RNAi) in vivo. J Biomed Biotechnol. 2006

50. Behlke MA. Progress towards in vivo use of siRNAs. Mol Ther. 2006; 13:644-670. [PubMed: 16481219]

51. Dalby B, Cates S, Harris A, Ohki EC, Tilkins ML, Price PJ, Ciccarone VC. Advanced transfection with Lipofectamine 2000 reagent: primary neurons, siRNA, and high-throughput applications. Methods. 2004; 33:95-103. [PubMed: 15121163]

52. Love TM, Moffett HF, Novina CD. Not miR-ly small RNAs: Big potential for microRNAs in therapy. J Allergy Clin Immun. 2008; 121:309-319. [PubMed: 18269923]

53. Patel LN, Zaro JL, Shen WC. Cell penetrating peptides: intracellular pathways and pharmaceutical perspectives. Pharm Res. 2007; 24:1977-1992. [PubMed: 17443399]

54. Gump JM, Dowdy SF. TAT transduction: the molecular mechanism and therapeutic prospects. Trends in molecular medicine. 2007; 13:443-448. [PubMed: 17913584]

55. Drin G, Cottin S, Blanc E, Rees AR, Temsamani J. Studies on the internalization mechanism of cationic cell-penetrating peptides. The Journal of biological chemistry. 2003; 278:31192-31201. [PubMed: 12783857] 
56. Duchardt F, Fotin-Mleczek M, Schwarz H, Fischer R, Brock R. A comprehensive model for the cellular uptake of cationic cell-penetrating peptides. Traffic. 2007; 8:848-866. [PubMed: 17587406]

57. Nakase I, Niwa M, Takeuchi T, Sonomura K, Kawabata N, Koike Y, Takehashi M, Tanaka S, Ueda K, Simpson JC, Jones AT, Sugiura Y, Futaki S. Cellular uptake of arginine-rich peptides: roles for macropinocytosis and actin rearrangement. Mol Ther. 2004; 10:1011-1022. [PubMed: 15564133]

58. Mager I, Langel K, Lehto T, Eiriksdottir E, Langel U. The role of endocytosis on the uptake kinetics of luciferin-conjugated cell-penetrating peptides. Biochimica et biophysica acta. 2012; 1818:502-511. [PubMed: 22155257]

59. Khalil IA, Kogure K, Futaki S, Harashima H. High density of octaarginine stimulates macropinocytosis leading to efficient intracellular trafficking for gene expression. The Journal of biological chemistry. 2006; 281:3544-3551. [PubMed: 16326716]

60. Tamaru M, Akita H, Fujiwara T, Kajimoto K, Harashima H. Leptin-derived peptide, a targeting ligand for mouse brain-derived endothelial cells via macropinocytosis. Biochemical and biophysical research communications. 2010; 394:587-592. [PubMed: 20214882]

61. Walsh M, Tangney M, O'Neill MJ, Larkin JO, Soden DM, McKenna SL, Darcy R, O'Sullivan GC, O'Driscoll CM. Evaluation of cellular uptake and gene transfer efficiency of pegylated poly-Llysine compacted DNA: implications for cancer gene therapy. Molecular pharmaceutics. 2006; 3:644-653. [PubMed: 17140252]

62. Zorko M, Langel U. Cell-penetrating peptides: mechanism and kinetics of cargo delivery. Advanced drug delivery reviews. 2005; 57:529-545. [PubMed: 15722162]

63. Ziegler A, Nervi P, Durrenberger M, Seelig J. The cationic cell-penetrating peptide Cpp(TAT) derived from the HIV-1 protein TAT is rapidly transported into living fibroblasts: Optical, biophysical, and metabolic evidence. Biochemistry. 2005; 44:138-148. [PubMed: 15628854]

64. Uitto J, Pulkkinen L. The genodermatoses: Candidate diseases for gene therapy. Hum Gene Ther. 2000; 11:2267-2275. [PubMed: 11084685] 


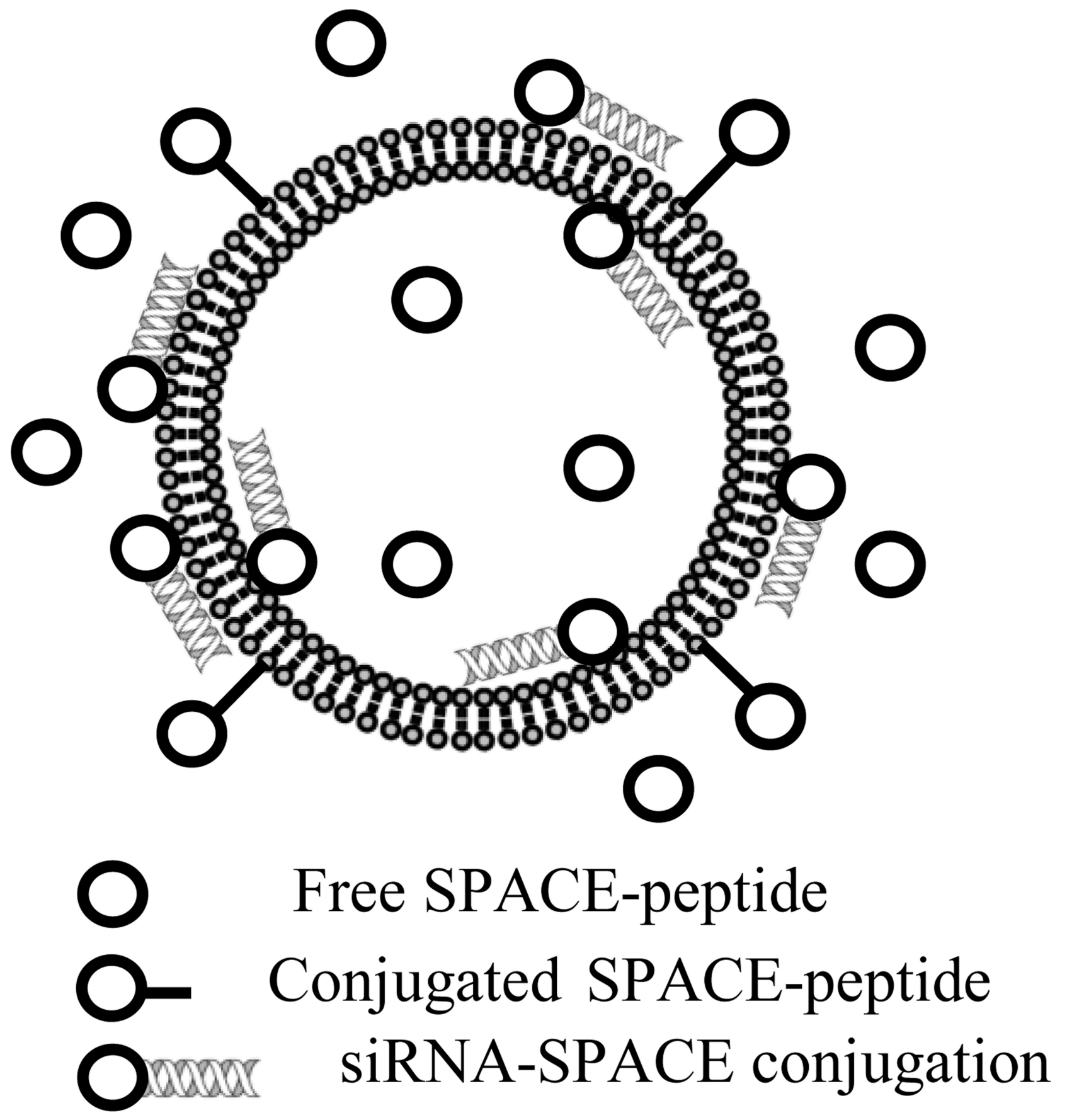

Figure 1.

Schematic of SPACE-peptide decorated cationic ethosomes (DOTAP-SES) used for topical delivery of siRNA. SPACE peptide is present at three places: direct conjugation to siRNA, direct conjugation to ethosomal particle surface and free form. 
(a)

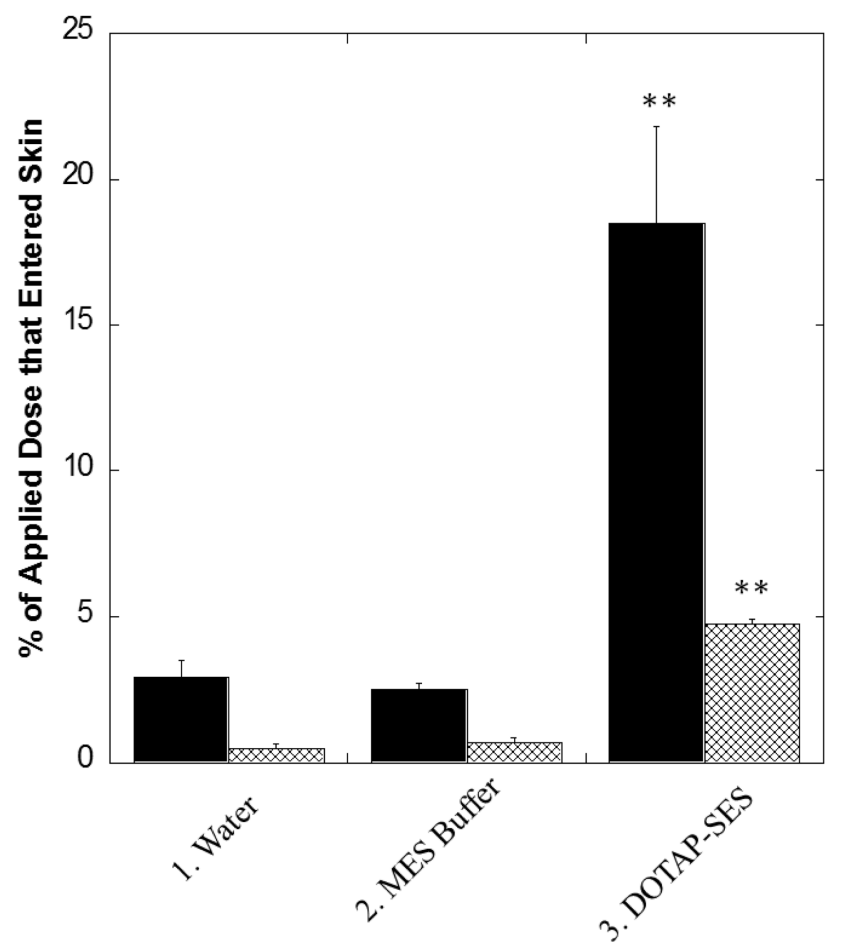

(b)

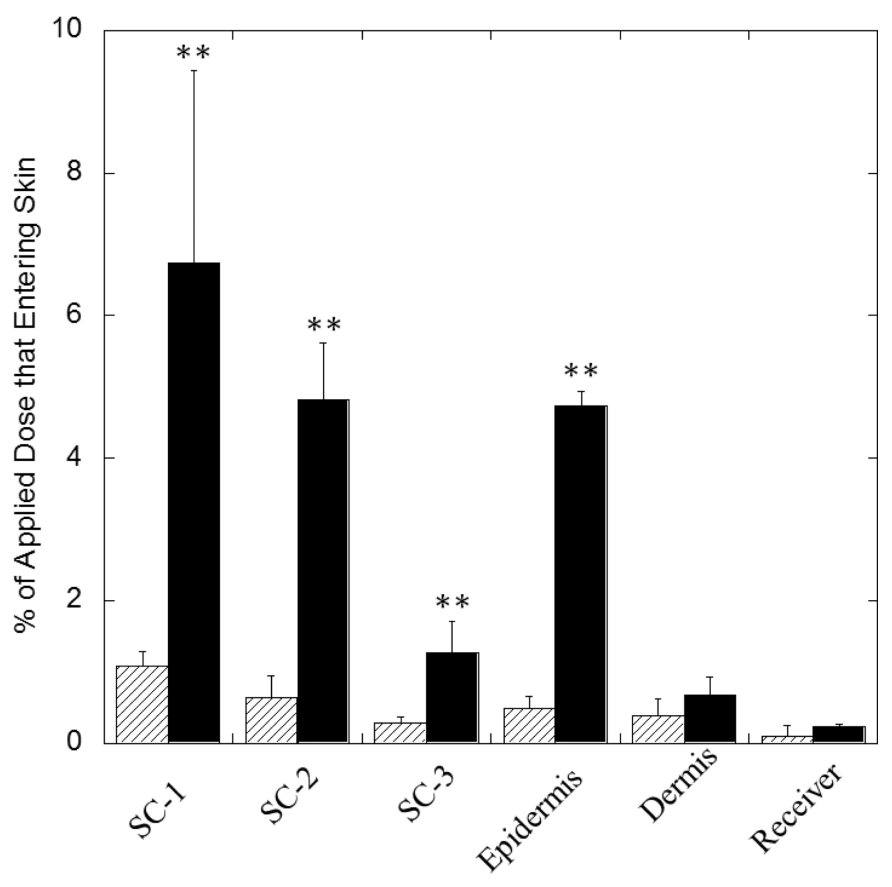

Figure 2.

DOTAP-SES enhances penetration of GAPDH-siRNA into porcine skin in vitro. (a) Percent penetration of topically applied dose into skin. Black solid bar: Percent penetration of topically applied dose into total skin. Crosshatch bar: Percent penetration of topically applied dose into epidermis. DOTAP-SES formulation demonstrated significantly greater total skin $(18.5 \% \pm 3.3 \%, p<0.01$ versus all other groups) and epidermal penetration of GAPDH-siRNA $(4.8 \% \pm 0.8 \%, p<0.01$ versus all other groups). Water: GAPDH-siRNA (25 $\mu \mathrm{M})$ in water solution; MES: GAPDH-siRNA $(25 \mu \mathrm{M})$ in MES buffer (pH 5.5). Values represent mean \pm SD ( $n=3)$; DOTAP-SES: Cationic SPACE-DOTAP-Ethosomal System with SPACE peptide conjugated phospholipids $(2 \mathrm{mg} / \mathrm{mL})$ containing GAPDH-siRNASPACE conjugation $(25 \mu \mathrm{M})$ and free SPACE-peptide $(50 \mathrm{mg} / \mathrm{mL})$ (Ethanol/MES buffer, $\mathrm{pH} 4.0,45 \%, \mathrm{v} / \mathrm{v}$ ); (b) Skin penetration and distribution profile of GAPDH-siRNA from DOTAP-SES formulation. Forward slash bar: GAPDH-siRNA from water solution; Solid black bar: GAPDH-siRNA from DOTAP-SES formulation. SC-1 corresponds to 1st strip, SC-2 corresponds to collection of 2 nd -5th strips and SC-3 corresponds to collection of 6th -10 th strips. DOTAP-SES formulation demonstrated significantly enhanced accumulation in SC layers $(12.8 \% \pm 3.4 \%, p<0.01$ versus water control) and in viable epidermis $(4.7 \% \pm 0.2 \%$, $p<0.01$ versus water control). Values represent mean $\pm \mathrm{SD}(\mathrm{n}=3) * *$ Statistically very different from PBS groups $(p<0.01)$. 


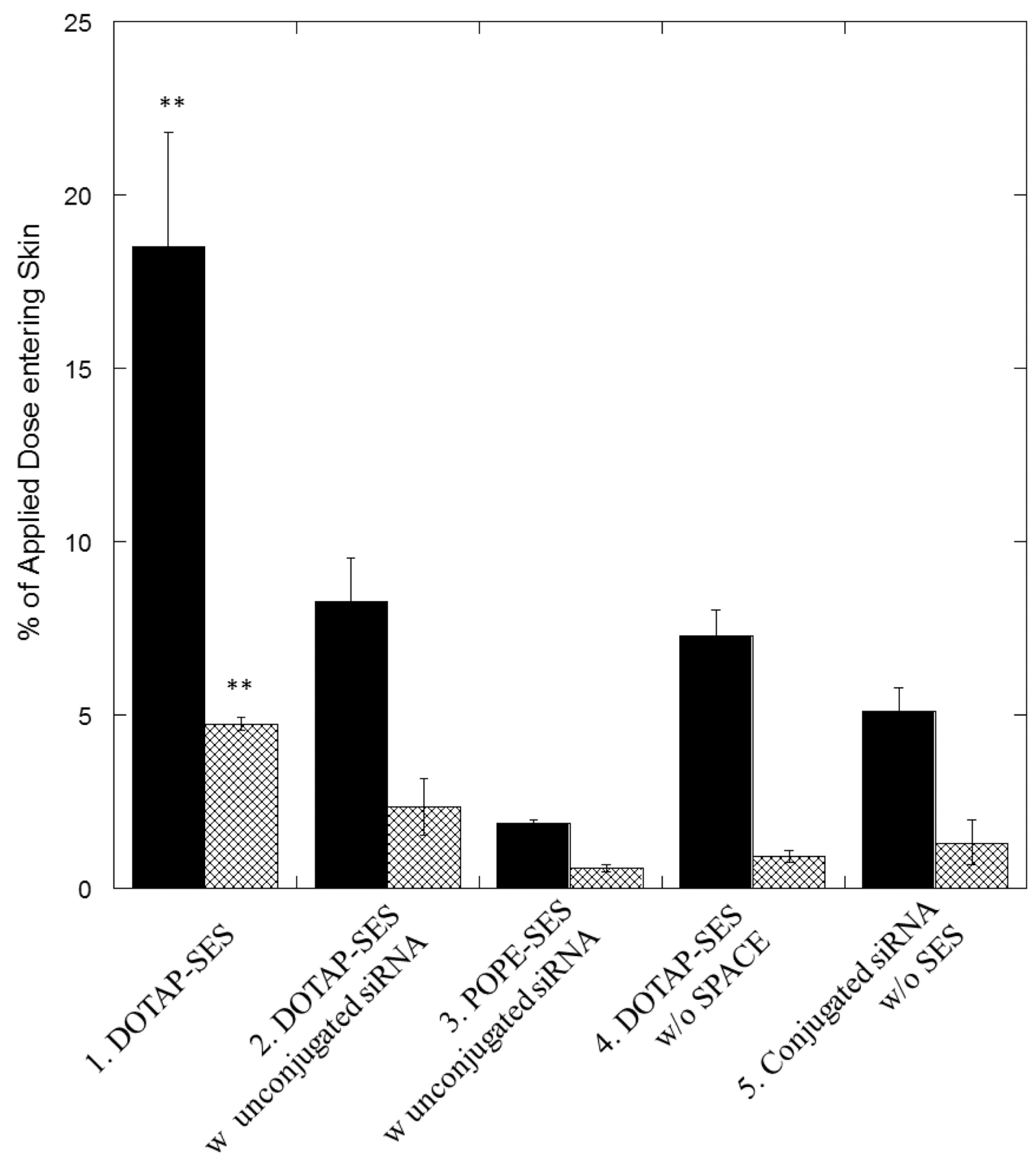

Figure 3.

The role of various components of DOTAP-SES formulation on skin penetration of GAPDH-siRNA. Black solid bar: Percent penetration of topically applied dose into total skin. Crosshatch bar: Percent penetration of topically applied dose into epidermis. DOTAP lipid and SPACE peptide (present at all three places: direct conjugation to siRNA, direct conjugation to ethosomal particle surface and free form) contribute to the enhanced skin absorption of GAPDH-siRNA from DOTAP-SES formulation. DOTAP-SES: Cationic SPACE-DOTAP-Ethosomal System with SPACE peptide conjugated phospholipids (2 
$\mathrm{mg} / \mathrm{mL}$ ) containing GAPDH-siRNA-SPACE conjugation $(25 \mu \mathrm{M})$ and free SPACE-peptide $(50 \mathrm{mg} / \mathrm{mL})($ Ethanol/MES buffer, $\mathrm{pH} 4.0,45 \%, \mathrm{v} / \mathrm{v})$; DOTAP-SES w unconjugated siRNA: Cationic SPACE-DOTAP-Ethosomal System with SPACE peptide conjugated phospholipids $(2 \mathrm{mg} / \mathrm{mL})$ containing GAPDH-siRNA $(25 \mu \mathrm{M})$ and free SPACE-peptide (50 $\mathrm{mg} / \mathrm{mL}$ ) (Ethanol/MES buffer, $\mathrm{pH}$ 4.0, 45\%, v/v); POPE-SES w unconjugated siRNA:

Anionic SPACE-Ethosomal system formulation with SPACE peptide conjugated phospholipids $(2 \mathrm{mg} / \mathrm{mL})$ containing GAPDH-siRNA $(25 \mu \mathrm{M})$ and free SPACE-peptide (50 $\mathrm{mg} / \mathrm{mL}$ ); DOTAP-SES w/o SPACE: Cationic DOTAP-Ethosomes alone containing GAPDH-siRNA $(25 \mu \mathrm{M})$ (Ethanol/PBS buffer, $\mathrm{pH} 4.0,45 \%$, v/v); Conjugated siRNA w/o SES: GAPDH-siRNA-SPACE conjugation $(25 \mu \mathrm{M})$ in MES buffer ( $\mathrm{pH} 5.5)$. Values represent mean $\pm \mathrm{SD}(\mathrm{n}=3)$. $* *$ Statistically very different from all other groups $(p<0.01)$. 
(a)

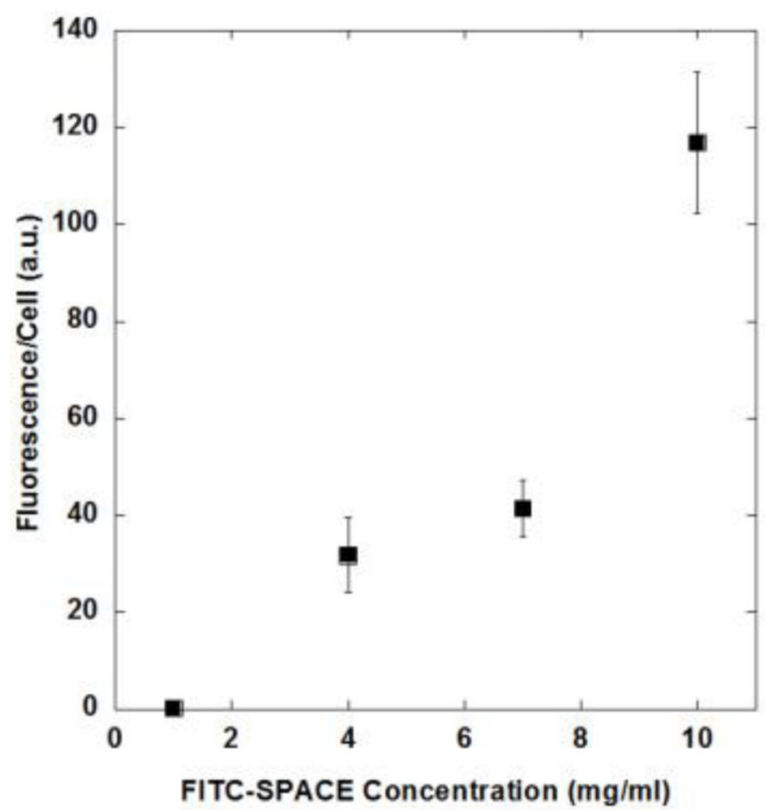

(c) (b)

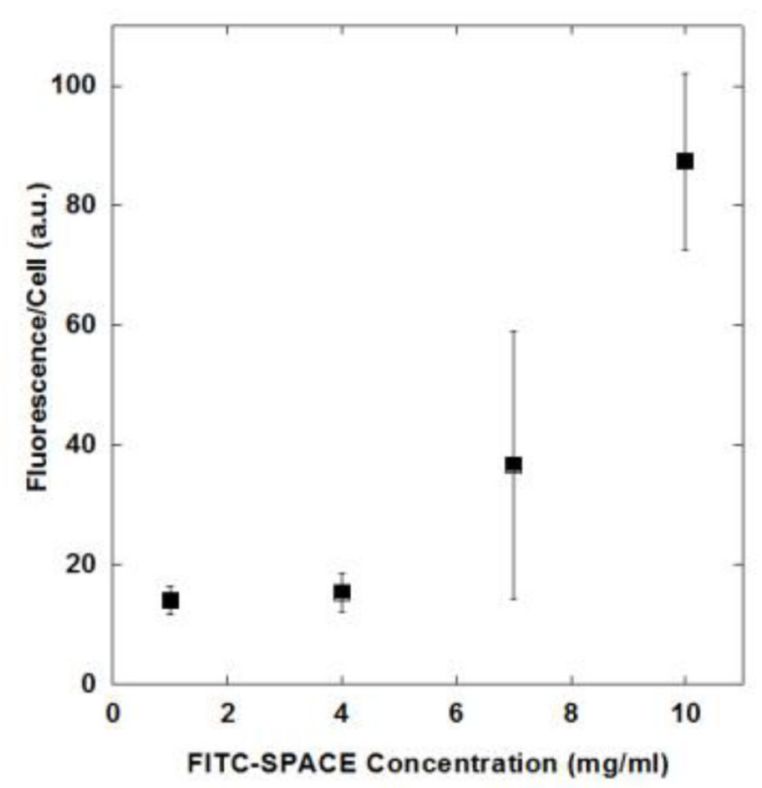

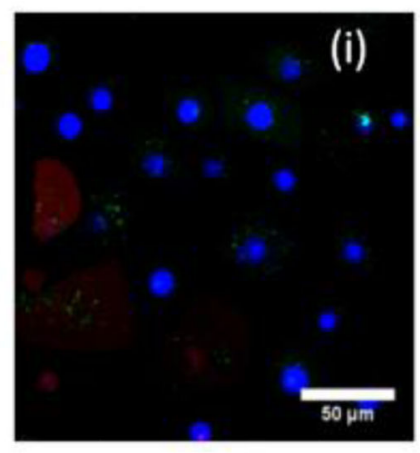
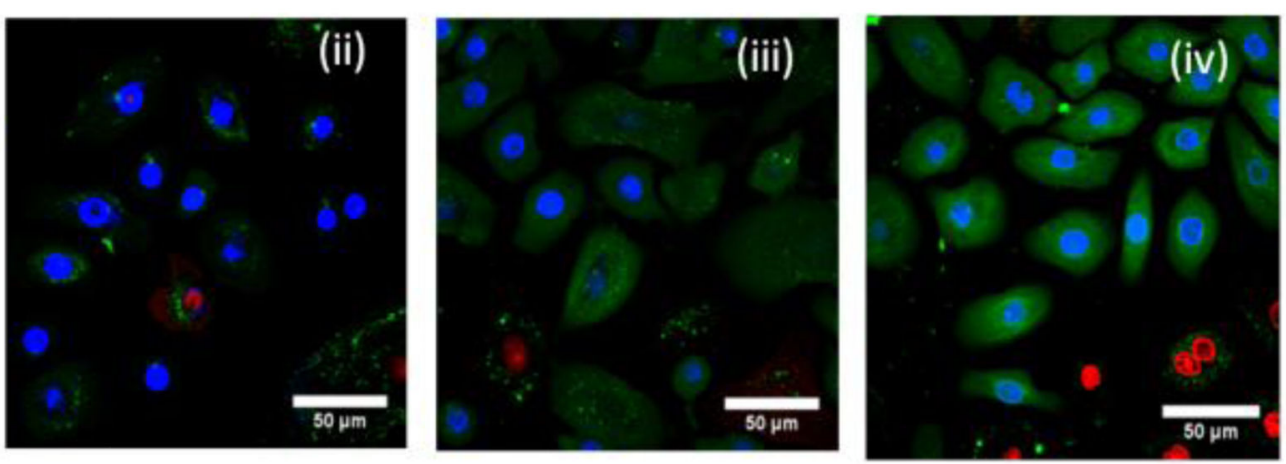

Figure 4.

SPACE peptide facilitates the internalization of a model drug, FITC, in a concentration dependent manner. Internalization of FITC-SPACE peptide measured for (a) 30 min or (b) 120 min incubation times. Representative images (c) showing FITC internalization after 120 min incubation at (i) $1 \mathrm{mg} / \mathrm{mL}$, (ii) $4 \mathrm{mg} / \mathrm{mL}$, (iii) $7 \mathrm{mg} / \mathrm{mL}$, or (iv) $10 \mathrm{mg} / \mathrm{mL}$ FITC-SPACE peptide. Nuclei were stained with Hoechst 33342 (blue) and dead cells indicated by Ethidium Bromide staining (red) were ignored during analysis. Values represent mean \pm SD $(n=3)$. 


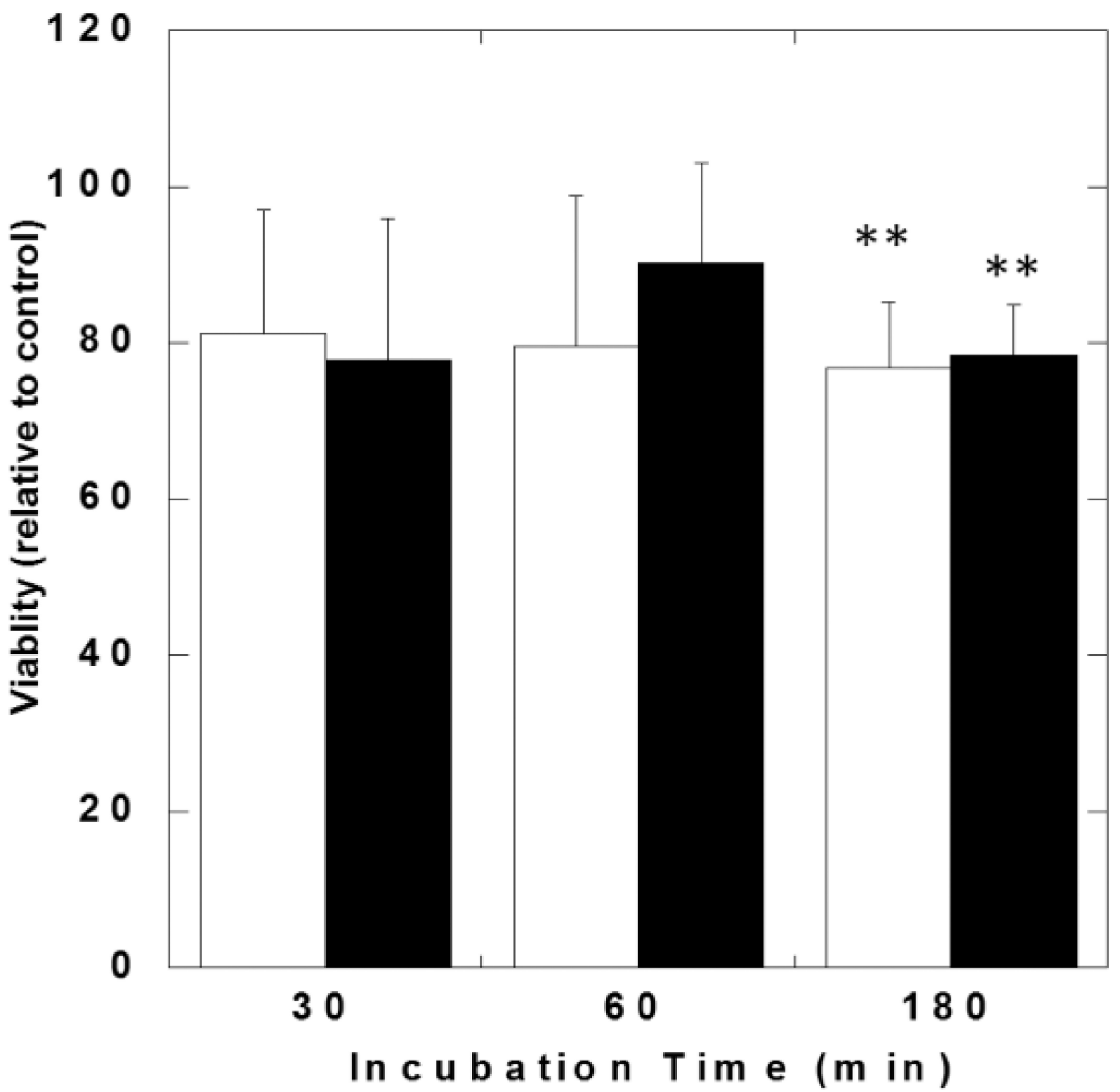

Figure 5.

Toxicity of $1 \mathrm{mg} / \mathrm{mL}$ (open bars) and $10 \mathrm{mg} / \mathrm{mL}$ (closed bars) SPACE peptide incubated with human adult epidermal keratinocytes for $30 \mathrm{~min}, 60 \mathrm{~min}$, and $180 \mathrm{~min}$. Values represent mean $\pm \mathrm{SD}(\mathrm{n}=3)$. ** Significantly very different from control $(p<0.01)$. 


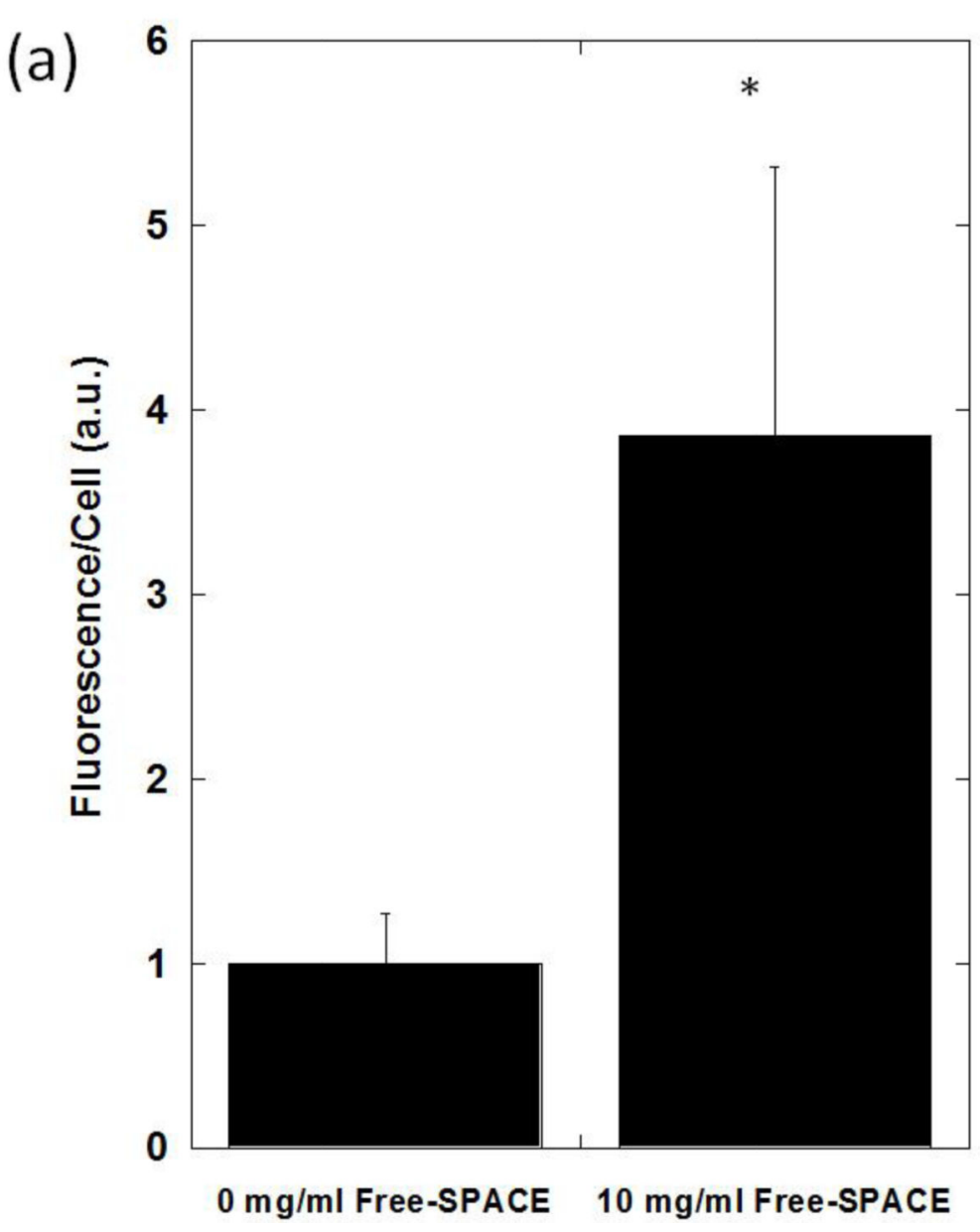

(b)

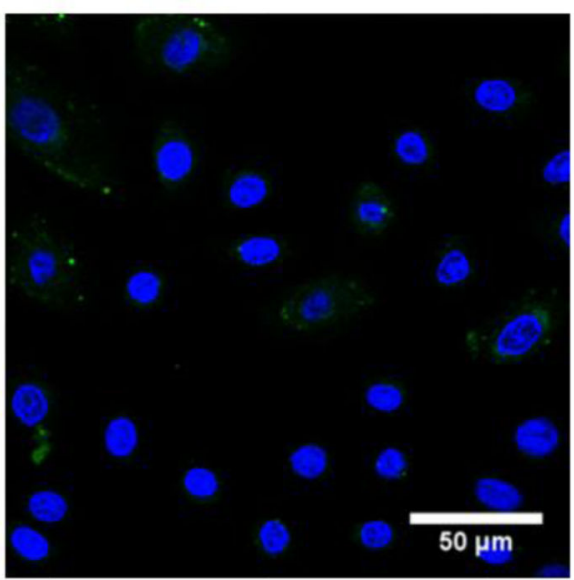

Figure 6.

Free SPACE peptide increases internalization of a model drug, FITC, and shifts the intracellular distribution from endocytotic structures into the cytoplasm. (a) Internalization of FITC into human adult epidermal keratinocytes when incubated for 15 min with 0.1 $\mathrm{mg} / \mathrm{mL}$ FITC-SPACE peptide with or without $10 \mathrm{mg} / \mathrm{mL}$ free SPACE peptide.

Representative images of internalization and intracellular localization when incubated with (b) $0 \mathrm{mg} / \mathrm{mL}$ free SPACE peptide or (c) $10 \mathrm{mg} / \mathrm{mL}$ free SPACE peptide. Values represent mean $\pm \mathrm{SD}(\mathrm{n}=3)$. *Significant difference between $10 \mathrm{mg} / \mathrm{mL}$ free SPACE peptide and 0 $\mathrm{mg} / \mathrm{mL}$ free SPACE peptide conditions $(p<0.05)$. 


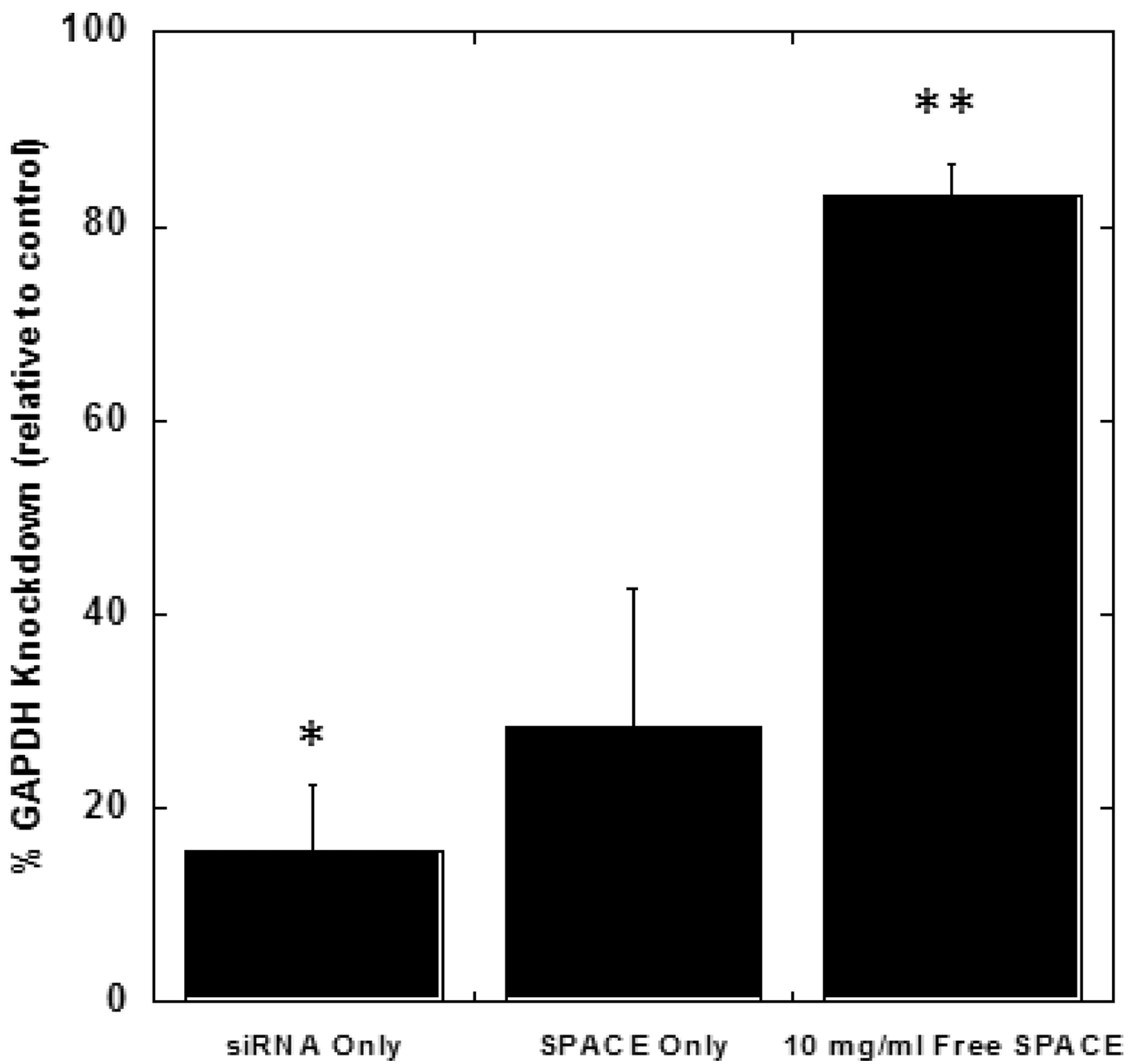

Figure 7.

Conjugation to SPACE peptide and co-incubation with free SPACE peptide induced knockdown of GAPDH protein in human adult epidermal keratinocytes. siRNA Only: $1 \mu \mathrm{M}$ GAPDH siRNA in media; SPACE Only: $10 \mathrm{mg} / \mathrm{mL}$ free SPACE peptide in media; 10 mg/mL Free SPACE: $1 \mu \mathrm{M}$ GAPDH siRNA-SPACE peptide co-incubated with $10 \mathrm{mg} / \mathrm{mL}$ Free SPACE peptide in media. Control was media alone. Values represent mean $\pm S E(n=6)$. $*$ Significantly different from the control $(p<0.05)$. **Significantly different from all other formulations $(p<0.01)$. 


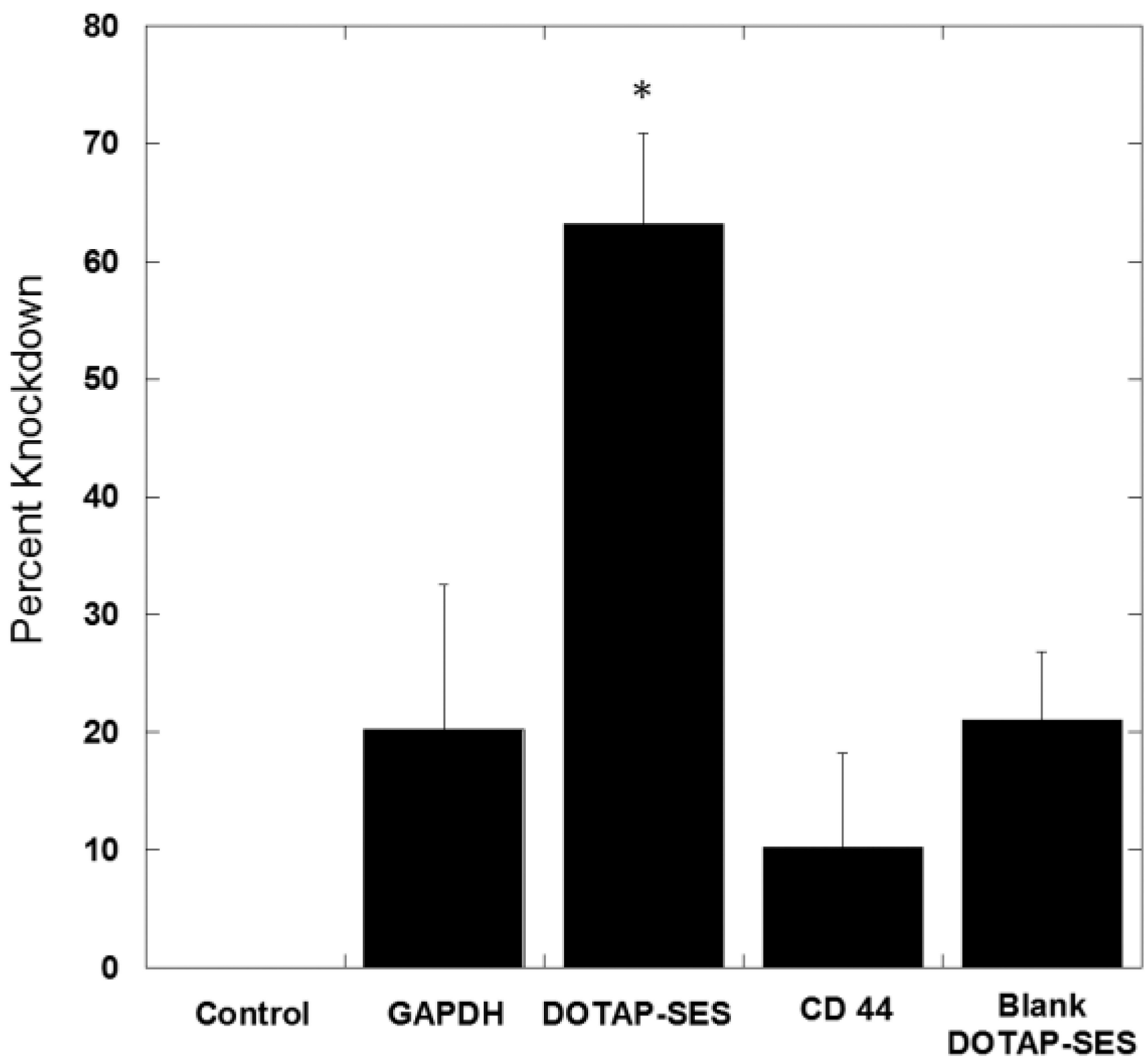

Figure 8.

DOTAP-SES induced the knockdown of GAPDH protein in Balb/C mice skin after $72 \mathrm{hrs}$ treatment in vivo. All formulations contain $25 \mu \mathrm{M}$ of GAPDH-siRNA. Control: $0.9 \%$ Saline; GAPDH: GAPDH-siRNA $(25 \mu \mathrm{M})$ in PBS (pH 8.0); DOTAP-SES: Cationic SPACEDOTAP-Ethosomal System with SPACE peptide conjugated phospholipids $(2 \mathrm{mg} / \mathrm{mL})$ containing GAPDH-siRNA-SPACE conjugation $(25 \mu \mathrm{M})$ and free SPACE-peptide (50 $\mathrm{mg} / \mathrm{mL}$ ) (Ethanol/MES buffer, $\mathrm{pH} 4.0,45 \%$, v/v); CD44: CD44-siRNA in PBS (pH 8.0); Blank DOTAP-SES: DOTAP-SES formulation without GAPDH-siRNA. Values represent mean $\pm \operatorname{SE}(n=6) *$ Statistically different from all other groups $(p<0.05)$. 
(a)

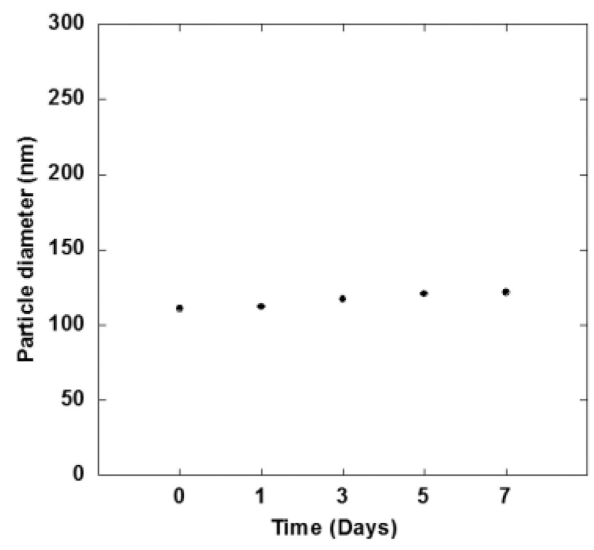

(b)

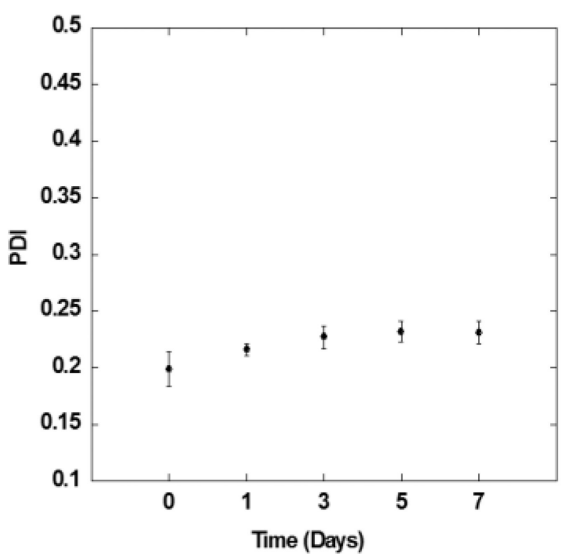

(c)

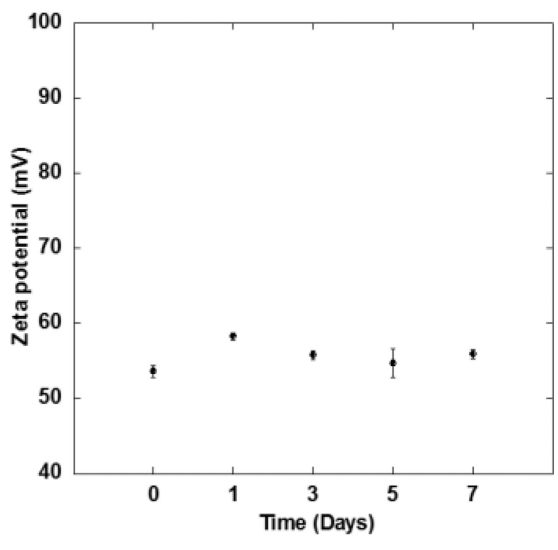

Figure 9.

DOTAP-SES formulation is stable for one week. $(\mathrm{a}, \mathrm{b})$ Particle size distribution of DOTAP-

SES formulation as a function of time (stored at $4{ }^{\circ} \mathrm{C}$ ); (c) $\zeta$-potential of DOTAP-SES formulation as a function of time (stored at $4{ }^{\circ} \mathrm{C}$ ). 